\title{
The Influence of Essential oils Supplementation on Yield and Quality of Sheep milk
}

\author{
Umit Ozcinar (Corresponding author) \\ Animal Nutrition and Nutritional Diseases Department, Faculty of Veterinary Medicine, \\ University of Afyon Kocatepe, ANS Campus, Afyonkarahisar/ Turkey \\ E-mail: umitozcinar@gmail.com \\ Ismail Bayram \\ Animal Nutrition and Nutritional Diseases Department, Faculty of Veterinary Medicine, \\ University of Afyon Kocatepe, ANS Campus, Afyonkarahisar/ Turkey \\ E-mail: ibayram1965@gmail.com
}

\begin{abstract}
Throughout the world major proportion of milk is obtained from large dairy animals, cows and buffaloes, however there is a considerable proportion of milk yield obtained from small dairy animals, sheep and goats. The share of milk production by sheep in total milk yield of the world is small because of different breeds having different genetic potential of milk production, managemental factors, environmental factors, nutritive factors, etc. The sheep milk is important because of cheese making. Due to microbial resistance, risk of drug residues either in milk, meat, or in eggs are dangerous for humans beings. So therefore the use of these synthetic compounds to improve immunity, health (antibiotics are used for growth promotion), and productivity (hormones are used to boost the milk production) in dairy animals is discouraged and the European Union has banned the use of these synthetic compunds in animals. So the phytobioactive compounds, essential oils, are used in feeds or rations of dairy animals to increase their production. These compounds are added not only to improve the milk yield but also to improve fat, protein and lactose contents of milk. The essential oils added in the diets of small dairy animals are usefull to counter the negative energy balance as well as the fatty acid profie to increase the quality of sheep milk.
\end{abstract}

Key words: Sheep milk, essential oils, milk yield

DOI: $10.7176 /$ JSTR/7-01-03

\section{Introduction}

The dairy animals (cows, buffaloes, sheep, goats, camel) have their respective share ( $81 \%$ from cow, $15 \%$ from buffaloes and the rest of $4 \%$ from goat, sheep and camel) in overall milk yield of the world and an increase has been seen in overall milk prodcution by 1,6\% in 2018 and it reached to 838 million tons. In the overall milk production of world, almost 1,4\% is obtained from sheep (OECD-FAO, 2018). The share of almost all dairy animals is increasing in total milk production and dairy products of the world and similarly the consumption of milk and dairy products obtained from sheep and goat is expected to increase by $26 \%$ and $53 \%$ respectively untill 2030 . The number of sheep and goats and the amount of milk for 2018 in the world are shown in Table 1.

The bulk of sheep milk is purchased by dairy industries and these process it to make cheese and majority is Protected Denomination of Origin (PDO) cheeses i.e. Pecorino, Man-chego, and Roquefort. Dairy products constitute for small portion of overall agricultural production in France, Italy and Spain $(0,9-1,8 \%)$ and in Greece $(8,8 \%)$ (Pulina et al., 2018). Milk yields in these countries is betweeen 85 to $216 \mathrm{~L} /$ sheep (Puli et al., 2018), in Turkey $77 \mathrm{~kg} /$ sheep has been reported. The ratio of the total milk production of milk obtained from sheep and goats in Turkey in 2019 was reported at 9.1\% (TUIK, 2020). In most of the Mediterranean and Eastern European countries milk and dairy 
products are obtained from dairy sheep breeds especially cheese and marketed for human consumption (Nudda et al., 2014).

Table 1: The number of sheep and goats in the world, the number of dairy sheep and goats, the total milk production and the distribution of their yields by continents (OECD-FAO, 2018).

\begin{tabular}{|l|c|c|c|c|c|c|c|c|}
\hline \multirow{2}{*}{ Continent } & \multicolumn{2}{|c|}{$\begin{array}{c}\text { Total (million } \\
\text { head) }\end{array}$} & \multicolumn{2}{|c|}{ Dairy (million head) } & \multicolumn{2}{c|}{ Milk (Mt) } & \multicolumn{2}{c|}{ Yield (L/head) } \\
\cline { 2 - 10 } & Sheep & Goats & Sheep & Goats & Sheep & Goats & Sheep & Goats \\
\hline Asia & 514 & 548 & 135 & 106 & 4.73 & 8.04 & 35.1 & 76.2 \\
\hline Africa & 383 & 438 & 79 & 80 & 2.54 & 3.93 & 32.2 & 48.9 \\
\hline Europe & 130 & 16,8 & 33 & 9 & 3.01 & 2.54 & 90.8 & 290.1 \\
\hline America & 82 & 38 & 3 & 8 & 0.09 & 0.75 & 33.0 & 93.4 \\
\hline Oceania & 97 & 4 & $<0.1$ & $<0.1$ & $<0.01$ & $<0.01$ & - & - \\
\hline Total & 1,209 & 1,045 & 250 & 203 & 10.37 & 15.26 & 41.5 & 75.3 \\
\hline
\end{tabular}

Today, despite of the developments in breeding methods, pastures and pasture grasses constitute the main source of feeding during the milk production period in sheep breeding. It is tried to meet the needs of sheep by adding silage, hay, alfalfa and concentrate feed mixes to their rations depending on the quality of the pastures (Molle et al., 2008). Chemically the fat contents of milk depend on ration, animal breed and environment (Pulina et al., 2006). Milk content data of some species are shown in table 2 .

Table 2: Milk ingredients by animal species (Gürsoy, 2019).

\begin{tabular}{|c|c|c|c|c|c|}
\hline Species & $\begin{array}{c}\text { Dry Matter } \\
(\boldsymbol{\%})\end{array}$ & $\begin{array}{c}\text { Milk fat } \\
(\boldsymbol{\%})\end{array}$ & $\begin{array}{c}\text { Protein } \\
(\boldsymbol{\%})\end{array}$ & $\begin{array}{c}\text { Lactose } \\
(\boldsymbol{\%})\end{array}$ & Ash (\%) \\
\hline Human & 12,4 & 3,8 & 1,0 & 7,0 & 0,2 \\
\hline Cow & 12,6 & 3,7 & 3,4 & 4,7 & 0,7 \\
\hline Buffalo & 17,2 & 7,4 & 3,5 & 5,4 & 0,8 \\
\hline Sheep & 19,3 & 7,4 & 5,5 & 4,8 & 1 \\
\hline Goat & 13,2 & 4,5 & 3,2 & 4,1 & 0,8 \\
\hline
\end{tabular}

Increasing animal production in the world has always been a current issue and various researches have been made and continue to be done for this purpose. Medicines, antibiotics, vitamin-mineral premixes, feed additives and herbal extracts have been used in order to increase the yields obtained from animals. In today's studies, the residue problem of drugs and antibiotics has made scientists think and the arrows have turned into plants, herbal extracts (Wang et al., 2000). Since herbal extracts increase the yield performance and do not contain residue risk like drugs, they have managed to take the first place as a preference (Sharma, 2007).

\section{Milk Fat Content}

Lipids, an important source of energy, perform important biological functions by being in the basic structure of the cell membranes and signal mediators related to the events developing in the cell. It has functions such as forming the structural components of cell membranes, prostaglandin synthesis and attaching proteins to cell membranes. The fatty acids (FA) that make up lipids are also stored as intracellular triacylglycerides in lipid droplets and provide a powerful source of energy when the body needs it (Santos et al., 2013).

In milk, fat is found as globules having various sizes in which nuclei of triglycerides present in threelayered membrane. The physiology, genetics and environment affect the concentration and diameter 
of fat globules in milk (Martini et al., 2004). The lipids in sheep milk are derived from glycerol, 3 fatty acids and different carbon chains. For fatty acid synthesis, mammary gland epithelial cells are needed and synthesized by plasma through the process of de novo synthesis. The source of the fatty acid produced by the process of de novo synthesis is acetate and betahydroxybutyrate produced through rumen fermentation. The volatile FA are main carbon sources for secretory cells of mammary gland, which are also involved in the de novo synthesis of some of SCFA (C4:0-C14:0) and C16:0). The remainder of $\mathrm{C} 16: 0$ in milk and all long chain fatty acids (C18:0-C22:0) come from lipids circulating in the blood stream, resulting from absorption in the small intestine. Indeed, fatty acids having chain length of 14-18 carbons can be modified by activity of desaturase in mammary gland. Also, the milk fat is composed of strange and branched-chain fatty acids derived from intestinal uptake of lipids from bacterial membrane differentiating from rumen (Vlaeminck et al., 2006).

The definition of more than 400 fatty acids with the complex FA composition of milk fat causes formation of triglycerides with different physical and chemical properties (Jensen, Ferries \& LammiKeefe, 1991; Gresti et al., 1993). At least 12 of these fatty acids are present in an amount $>0,01 \%$ (Jensen, 2002). The chemical structure of milk fat causes the melting range between -40 and $+40^{\circ} \mathrm{C}$ to emerge (Boudreau and Arul, 1993; Breitschuh and Windhab, 1998). Manny factors affect to fatty acids composition, source of milk, genetics, nutrition, environmental, etc. (Jensen, Ferries \& LammiKeefe, 1991; Hinrichs, Heinemann \& Kessler, 1992). The solid to liquid ration determines functional properties of milk fat i.e. hardness, viscosity, spreadability, plasticity, heat transfer and compatibility with other oils (Kaylegian, 1995). Fat contents of milk are determined by the measurement of the percentage of fat $(\% \mathrm{w} / \mathrm{w})$ at a given temperature, depending on the reference conditions, is effective in determining the physical properties of the oil (Kaylegian and Lindsay, 1995). Kaylegian and Lindsay (1995), in their study on milk fat, increased short chain saturated fatty acids (C4:0-C10:0) and long chain unsaturated fatty acids (C16:1-C18:1), saturated fatty acids (C16) increased:0-C18:0), they found that low melting point milk fat increased. This had a reduced melting point and fat content profile. Solid fat content can be measured using pulsed nuclear magnetic resonance and differential scanning calorimetry (Kaylegian and Lindsay 1995). Pulsed nuclear magnetic resonance is among the most preferred techniques in recent years.

The type and level of fatty acids that make up milk fat are particularly affected by fatty acids in feed (Grummer, 1991; Hermansen, 1995). The milk fat contents are altered through feed mostly by factors which can affect fermentation in rumen. In fact, the acetate:propionate content in ruminal fluid performs an important role in milk lipid synthesis in ruminants (Nudda et al., 2014).

Like fatty acid soaps, the addition of rumen bypass oil in the diets of dairy sheep is a good strategy to improve milk fat contents. Generally it is observed that rations incorporating palm oil and Ca salts at levels varying between 90-200 g/day increase milk yield and milk fat percentage, but using higher doses tends to decrease yield (Pulina et al., 2006). Tuna oil and olive oil added to the feed for the same purpose did not reduce the milk fat content. It is observed that flaxseed improved milk fat contents of goats milk in mid lactation period, but decreased milk fat contents in lactating sheep. (Gómez-Cortés et al., 2014).

\section{Essential Oils and Properties}

Aromatic (essential) oils are compounds with pungent odor, volatile, liquid at room temperature and easily crystallized, obtained from the leaves, buds, seeds, flowers, and roots of plants by different methods (Bakkali et al., 2008). These substances are produced by plants in order to reproduce, maintain life and protect themselves against certain pests. These produced substances are expressed with different names such as essential oil, aromatic oil, essential oil, ethereal oil or vegetable oil (Benchaar et al., 2007). There are about 3000 essential oils (EO's) are known and out of which 300 EO's are used in animal nutrition, agriculture, food, perfume industry, etc. These are extracted from phytogenic sources and are used in diets of dairy animals due to their beneficial and productive charcateristics i.e. antibacterial, antifungal, insecticidal activities etc. (Silva et al., 2003).

\section{The Effect of Essential Oils on Milk Fat Content}

The lipids are significant because of nutritive value and their beneficial influence on the physicochemical, sensory and production characteristics in sheep milk (Park et al., 2007). The FA profile of milk fat is influenced by a number of genetic factors, physiological factors and environment (Pulina et al., 2006). In sheep and goat milk, SCFA and medium chain fatty acid contents are significantly higher than in cow's milk for caproic, caprylic, capric and lauric acid (Alonso et al.,

32 | $\mathrm{P}$ a g e

www.iiste.org 
1999). The sheep milk also contains high contents of butyric acid, CLA and omega 3 fatty acid as compared to ruminant's milk (Colombatto, Mcallister \& Beauchemin, 2008).

The EOs' have a specific antibacterial activity against Gram -ve and Gram +ve bacteria and many EOs' perform biohydrogenation of USFA in the rumen (Helander et al., 1998). Benchaar et al., (2007), observed no change in the milk FA profile when $750 \mathrm{mg}$ of mixed essential fatty acid were offered to cows. However, it was observed that offering same mixture at a bit higher concentration (2 g/day) increased the concentration of CLA.

Table 3: Addition of different doses of essential oil by Giannenas et al., (2011).

\begin{tabular}{|c|c|c|c|c|}
\hline Day/ 50 & Control & E. Oil. 50 $\mathbf{~ m g / k g}$ & $\begin{array}{c}\text { E. Oil. 100 } \\
\mathbf{~ m g / k g}\end{array}$ & $\begin{array}{c}\text { E. Oil. 150 } \\
\mathbf{~ m g / k g}\end{array}$ \\
\hline Milk (L/d) & 1.83 & 1.86 & 2.20 & 2.49 \\
\hline Fat (g/d) & 13.1 & 13.4 & 15.9 & 17.9 \\
\hline Fat (\%) & 7.15 & 7.22 & 7.25 & 7.21 \\
\hline Protein (g/d) & 10.3 & 10.6 & 12.5 & 14.3 \\
\hline Protein (\%) & 5.65 & 5.72 & 5.70 & 5.75 \\
\hline Lactose (g/d) & 9.0 & 9.0 & 10.5 & 11.7 \\
\hline
\end{tabular}

In a study (Table 3), three different doses of daily essential oil were added to sheep rations. Especially the addition of high doses of essential oil showed significant effects on milk fat, milk protein and lactose levels in sheep. Milk fat, milk protein and milk lactose concentration can be increased by supplementing the diets of sheep with high level of EOs' (Giannenas et al., 2011).

Abeer et al., (2020) added anise, clove and thyme essential oils to the ration in a study they conducted on dairy goats. In the study, it was stated that the addition of $2 \mathrm{ml} / \mathrm{goat} /$ day essential oil to the ration had no affects on feed consumption and milk production, but increased rumen fermentation. In addition, it has been shown that the polyunsaturated FA formed by adding clove and thyme oil increase more than the anise group.

In a study conducted in dairy sheep (Symeou et al., 2019) the effect of olive raw material used in olive oil production to the rations in certain proportions and the effect of fatty acids and cholesterol content in milk was investigated. In the study, milk fatty acids were affected, but there was no change in cholesterol, lowered the saturated FA contents, an increase in USFA, as well as conjugated linoleic acid and linolenic acid contents were also increased. Muñoz-Tébar et al., (2019), conducted a study in sheep cheese using chia oil (Salvia hispanica L.). In this study, chia oil at 3 and $5 \mathrm{~g} / 1$ concentrations stabilized with calcium caseinate was applied to pressed and incubated sheep cheese. The parameters (organoleptic, physicochemical, and microbiological) were evaluated for 32 days. As a result, the coagulation parameters of milk during cheese making did not change with the addition of fat. On the other hand, adding chia oil has been reported to have a positive effect on cheese production, fat, DM and $\alpha$-linolenic acid. In addition, it has been shown that the total amount of bacteria and the growth of lactogenic bacteria are not inhibited even in a group with high added oil, which confirms their hypothesis that adding oil may not affect the normal maturation process.

Pascual et al., (2019) observed that sensory properties of fatty acids of milk and curd cheese as a result of the addition of cold pressed oil seeds to dairy sheep rations. Meadow grass and sainfoin grass were used as roughage sources in the rations of animals, and ground palm oil, coldpress sunflower, coldpress rapeseed were used as oil sources in concentrated feeds. A decrease was observed in the overall concentration of milk FA in the group with sunflower added as an oil source, and this decrease was also observed when rapeseed was used with only the ration using sainfoin as roughage. An increase in unsaturated fatty acids was reported when sunflower and rapeseed used as two different oil sources were added to rations made with sainfoin as roughage. It has been stated that milk production is not affected by any fat added to the ration. They stated that, due to the abundance of olive cultivation in Mediterranean countries, the use of olive industry residues in animal feeding and especially the wastewater generated during olive processing has high phenolic concentration (Cappucci et al., 2018). The effect of these phenolic compounds on rumen fluid content and milk fatty acids in sheep was investigated, and it was shown that the use of 0.8 and $1.2 \mathrm{~g} / \mathrm{kg}$ dry matter did not change the milk yield, but the amount of linoleic acid and $\alpha$-linolenic acid was increased (Cappucci et al., 2018). In the study conducted by treating olive and fish oils with calcium soaps, impacts of EOs' on lactating sheep milk and on the subcutaneous adipose tissue and muscle tissue of lambs fed with 33 | P a g e www.iiste.org 
these milk were investigated. According to the results obtained by adding 3\% olive and $3 \%$ fish oil to the rations of the sheep, the milk yield was not affected, although the milk production was not affected in the fish oil group, it was observed that the milk fat concentration was reduced. It has been stated that changes in milk fat concentration enable lambs to store polyunsaturated fatty acids in muscle tissue instead of fat tissue (Gallardo et al., 2014).

\section{The Essential Oils Impacts on Milk Production}

There are some studies conducted to observe the effects of EOs' in lactating sheep, although their number has started to increase rapidly in recent years. While Giannenas et al., (2011), tested two doses of essential oils, Chiofalo et al., (2012), also tested two doses of essential oils in their study. In both studies, essential oils affected milk yield but not dry matter intake. In the experiment carried out in lactating sheep and goats, it was determined that the addition of essential oils to feed increased milk yield by $35 \%$. Interestingly, it was concluded that all concentrations given in this study caused a significant decrease in somatic cell count which could be a reason of improved milk production (Giannenas et al., 2011).

Santos et al., (2019) observed effects by adding agai (Euterpe oleracea) oil to the diets of sheep under heat stress on the blood parameters, milk production and milk quality of animals. The control group received $2 \%$ soybean oil and the other group $2 \%$ acacia oil, and the data on the $1^{\text {st }}, 10^{\text {th }}$ and $14^{\text {th }}$ days were evaluated. It was reported that leukocytes, neutrophils and lymphocytes in blood parameters, serum concentrations of triglycerides and urea and milk fat in the group using acai oil on the $14^{\text {th }}$ day were lower than the group using soybean oil. However, it was stated that glucose and globulin in serum, milk antioxidant capacity and milk production were higher in the acacia group. As a result, it has been observed that the use of acacia oil increases the antioxidant activity in milk and serum as well as the amount and quality of milk production.

Dry matter intake was not affected when anise, clove or thyme essential oils were given in addition to rations in pregnant ewes, but digestibility and nitrogen retention of foods were improved, especially with cloves and thyme. The rumen fermentation parameters were particularly affected by clove, while thyme had an effect on rumen microbial fermentation. Essential oils affect lipid metabolism resulting in the low fat content of animal products. It has been reported that milk production slightly increased in animals fed with cloves and thyme, and there was a significant improvement in milk composition and fatty acid profile. In addition, it was stated that the immunity of lambs born from these mother sheep improved, lamb mortality rates decreased and lamb growth rates were positively affected. Therefore, supplementing the diets of ruminants with EOs' can be promising and beneficial alternative feed supplement that enriches the nutritional properties of dairy products and thus provides value and benefit to animal products in terms of consumer health (Aberr, Ahlam \& Marwa, 2019). Based on this information, it is possible to predict that essential oil complexes are more effective after the begining of lactation, during periods of positive energy balance, in long-term studies and at high doses (Neto, Moreno \& Souza, 2016). Giannenas et al., (2011), observed a strong increase in daily milk production occurs with the addition of essential oil to sheep diets. In the experimental setup consisting of four groups: $50 \mathrm{mg} / \mathrm{kg}$ of essential oil was added to the first group, $100 \mathrm{mg} / \mathrm{kg}$ to the $2^{\text {nd }}$ group and $150 \mathrm{mg} / \mathrm{kg}$ to $3^{\text {rd }}$ group. While daily milk production in the control group was 1.83 liters, it was 1.86 in the first group, 2.20 in the second group and 2.49 in the third group. The contribution of high doses of essential oils on daily milk yield was positive. Particularly, the addition of a specific mixture of essential fat compounds at doses of 100 and $150 \mathrm{mg} /$ day showed significant effects on milk production, urea concentration in milk samples. The rumen urea, priopionate and acetate concentrations and microbial populations were affected by the dietary essential oil supplementation in early lactation of sakı dairy sheep. Long-term in vivo research trials are necessary to validate these results and elucidate the mechanisms of action in dairy sheep under various management conditions (Giannenas et al., 2011). Kholif et al., (2018), observed that addition of red pepper/thymus essential oil, enzyme addition, and comparative milk yields and monitoring of changes in milk in farafra sheep living in subtropical regions. In the mentioned study, milk yield increased by $14.5 \%, 11.7 \%$ and $16.6 \%$, respectively, in the groups where enzyme, essential oil and a mixture of both were used. In addition, USFA contents were increased and saturated FA concentration was lowered. Kotsampasi et al., (2018) tested the milk yield and composition in their studies in which dairy sheep added orange peel essential oil to their diets. As a result, the dose that increases daily milk yield is $300 \mathrm{mg}$ essential oil/kg concentrate, while the dose increasing feed utilization is $450 \mathrm{mg}$ essential oil $/ \mathrm{kg}$ concentrate feed. Milk fat saturated acids increased at $300 \mathrm{mg}$ dose, when the level was increased to $450 \mathrm{mg}$,

34 | P a g e

www.iiste.org 
USFA contents were lowered, blood plasma and milk antioxidant levels were increased.

Table 4: The impacts EO's on production, fat, protein content and lactose ratio of sheep milk

\begin{tabular}{|c|c|c|c|c|c|}
\hline Essential Oil & Milk yield & Milk fat \% & $\begin{array}{c}\text { Milk } \\
\text { Protein \% }\end{array}$ & $\begin{array}{c}\text { Milk } \\
\text { Lactose }\end{array}$ & References \\
\hline Anise & & & & & $\begin{array}{c}\text { Abeer, } \\
\text { Ahlam \& } \\
\text { Marwa, } \\
\text { 2019) }\end{array}$ \\
\hline Clove & & & & & $\begin{array}{l}\text { Abeer, } \\
\text { Ahlam \& } \\
\text { Marwa, } \\
\text { 2019) }\end{array}$ \\
\hline Thyme & & & & & $\begin{array}{l}\text { Abeer, } \\
\text { Ahlam \& } \\
\text { Marwa, } \\
\text { 2019) }\end{array}$ \\
\hline $\begin{array}{l}\text { thymol, } \\
\text { eugenol, } \\
\text { vanillin, } \\
\text { guaiacol, and } \\
\text { limonene } 100- \\
150 \mathrm{mg} / \mathrm{kg}\end{array}$ & & & & & $\begin{array}{c}\text { (Giannenas et } \\
\text { al., 2011) }\end{array}$ \\
\hline Garlic & & & & & $\begin{array}{c}\text { (Kholif et al., } \\
2012)\end{array}$ \\
\hline Cinnamon & & & & & $\begin{array}{c}\text { (Kholif et al., } \\
\text { 2012) }\end{array}$ \\
\hline Ginger Oil & & & & & $\begin{array}{l}\text { (Kholif et al., } \\
\text { 2012) }\end{array}$ \\
\hline Orange peel & & & & $\Leftrightarrow$ & $\begin{array}{l}\text { (Kotsampasi } \\
\text { et al., 2018) }\end{array}$ \\
\hline Thyme & & & & & $\begin{array}{c}\text { (Simitzis et } \\
\text { al., 2007) }\end{array}$ \\
\hline Lemon oil & & & & & $\begin{array}{c}\text { (Taissa et al., } \\
\text { 2017) }\end{array}$ \\
\hline
\end{tabular}

A research trial was performed and effects of celery containing EO's such as y-cadinene and thymol and thyme containing thymol, carvacrol, p-cymene, and y-cadinene on feed utilization and lactation in barki sheep ere observed. It was reported that thyme and celery added to feed increased feed intake, digestibility and serum glucose and thyroxine concentrations, and decreased rumen ammonia concentration. It has also been shown that total essential fatty acid and acetic acid increase the rumen concentration (Abd El Tawab et al., 2020). Recently, the interest of consumers in more natural products has increased and they tend to use natural and natural substances such as plant extracts that do not cause any harm to human health, instead of synthetic additives used in all foods. This deficit of the food industry has increased the inclination of scientists to this issue, and in line with this purpose, Granato et al., (2017), it was stated that these herbal extracts could be used to increase the sensory properties of yoghurt, cheese, ice cream and some fermented milk, to extend their usage time and to minimize the effects of synthetic products harmful to human health. On the other hand, 21 studies were evaluated that gave different results according to different sources of variation such as the age of the animal applied to the yield parameters of the essential oils used, the duration of essential acid use in the feed, extraction methods, and contents (Torres et al., 2020). The main ingredients in essential oils; It is stated to be carnosic acid, carvacrol and thymol. Addition of aromatic oil higher than $100 \mathrm{mg} / \mathrm{kg}$ dry matter to the ration reduces the daily body weight gain, and the use of higher than 
$200 \mathrm{mg} / \mathrm{kg}$ dry matter negatively affects the cutting weight, adding essential oil to the ration used for less than 30 days, rumen propionate and $\mathrm{NH}_{3}-\mathrm{N}$ concentrations gave the best results.

\section{Conclusion}

Feeding with essential oils gives better results in sheep and goats compared to bovine ruminants and ovine ruminants. Increase in milk yield and milk quality occurs in small ruminant rations supplemented with vegetable oils. The reason for this may be the fast transit time of feed from the rumen of small ruminants and less treatment with rumen bacteria. It has been observed that it is very important in the period to be preferred in feeding with vegetable oils. Since ruminants are in negative energy balance in the early stages of lactation, they can use the essential oils added to the diet to meet their own needs. However, essential oils added during the late lactation period can positively contribute to milk quality and yield. Essential oil supplementation in the early period of lactation can prevent the animal in negative energy balance from mobilizing open energy body fat. Based on this, it will be beneficial to feed with vegetable oil and extracts to be made in any period of lactation. The addition of essential oils may not only contribute to milk quality and milk yield, but also have effects such as rumen content and antimicrobial effects. The dose of essential oil to be added in diet to be supplemented with essential oils is important. As can be seen from the studies, adding high doses of essential oil gives better results on milk quality and milk yield. However, studies on the milk yield and quality of essential oils are quite limited. More studies are needed for the results to be more reliable.

\section{References}

Abd El Tawab, A.M. et al. (2020). Feed utilization and lactational performance of Barki sheep fed diets containing thyme or celery, Small Ruminant Research, 192, 106249, https://doi. org/ 10.1016/j.smallrumres.2020.106249.

Abeer, M. E. E. et al. (2021). Effects of anise, clove and thyme essential oils supplementation on rumen fermentation, blood metabolites, milk yield and milk composition in lactating goats, Animal Feed Science and Technology, 271, 114760, https://doi.org/10. 1016/ j.anifeedsci.2020.114760.

Abeer, M. E. E., Ahlam, R. A., \& Marwa, H.E.G. (2019). Impact of Anise, Clove, and Thyme essential oils as feed supplements on the productive performance and digestion of Barkiewes. Australian Journal of Basic and Applied Sciences, 13(6): 1-13. doi: 10.22587/ ajbas.2019.13.6.1

Alonso, L. et al. (1999). Fatty Acid Composition of Caprine Milk: Major, Branched-Chain, and Trans Fatty Acids. J. Dairy Sci.;82(5): 878-84.

Bakkali, F. et al. (2008). Biological effects of essential oils. Food and Chemical Toxicology $\mathrm{V}: 46,2 ; \mathrm{P}: 446-475$

Benchaar, C. et al. (2007). Effects of Essential Oils on Digestion, Ruminal Fermentation, Rumen Microbial Populations, Milk Production and Milk Composition in Dairy Cows Fed Alfalfa Silage or Corn Silage J. Dairy Sci. 90(2): 886-97.

Boudreau, A., \& Arul, J. (1993). Cholesterol Reduction and Fat Fractionation Technologies for Milk Fat: An Overview. Journal Dairy Science; 76, 1772-1781.

Breitschuh, B., \& Windhab, E. J. (1998). Parameters Influencing Cocrystallization and Polymorphism in Milk Fat. Journal of the American Oil Chemists' Society; 75, 897-904.

Cappucci, A. et al. (2018). Effect of increasing amounts of olive crude phenolic concentrate in the diet of dairy ewes on rumen liquor and milk fatty acid composition. Journal of Dairy Science, 101,6,4992-5005, https://doi.org/10.3168/jds.2017-13757 
Chiofalo, V. et al. (2012). Influence of dietary supplementation of Rosmarinus officinalis L. on performances of dairy ewes organically managed. Small Rumin. Res.; 104(1-3): 122-8.

Colombatto, D., Mcallister, T.A., \& Beauchemin, K.A. (2008). A review of plant-derived essential oils in ruminant nutrition and production. Animal Feed Science and Technology.145(924): 209-28.

Gallardo, B. et al. (2014). Effects of olive and fish oil Ca soaps in ewe diets on milk fat and muscle and subcutaneous tissue fatty-acid profiles of suckling lambs. Animal 1178-90. doi: $10.1017 /$ S 1751731114000238 .

Giannenas, I. et al. (2011). Effects of essential oils on milk production, milk composition, and rumen microbiota in Chios dairy ewes. J. Dairy Sci. ; 94(11): 5569-77.

Gómez-Cortés, P. et al. (2014). Effects of different sources of fat (calcium soap of palm oil vs. extruded linseed) in lactating ewes' diet on the fatty acid profile of their suckling lambs. Meat Sci.; 96(3): 1304-12.

Granato, D. et al. (2018). Effects of herbal extracts on quality traits of yogurts, cheeses, fermented milks, and ice creams: a technological perspective, Current Opinion in Food Science, 19, 1-7, https://doi.org/10.1016/j.cofs.2017.11.013.

Gresti, J. et al (1993). Composition of Molecular Species of Triacylglycerols in Bovine Milk Fat. Journal Dairy Science; 76, 1850-1869.

Grummer, Ric, R., (1991). Effect of feed on the composition of milk fat. Journal of Dairy Science, 74 (9), 3244-3257. https://doi.org/10.3168/jds.S0022- 0302(91) 78510-X

Gürsoy, Ayşe, (2019), Sütün bileşimi ve özellikleri. http://cv.ankara.edu.tr/ duzenleme/ kisisel/dosyalar/06012015013030.pdf.

Helander, I.M. et al. (1998). Characterization of the Action of Selected Essential Oil Components on Gram- Negative Bacteria. J. Agric. Food Chem.;46(9): 3590-5.

Hermansen, John, E., (1995), Prediction of milk fatty acid profile in dairy cows fed dietary fat differing in fatty acid composition. Journal of Dairy Science, 78 (4), 872-879. https://doi.org/10.3168/jds.S0022-0302(95)76700-5

Hinrichs, J., Heinemann, U., \& Kessler, H.G. (1992). Differences in the Composition of Triglycerides in Summer and Winter Milk Fat. Milchwissenschaft; 47, 494-498.

Jensen, R.G., Ferries, A.M., \& Lammi-Keefe, C.J. (1991). Symposium: Milk-Fat Composition, Function and Potential for Change. Journal Dairy Science, (74, 3228-3243.

Jensen, Robert, G., (2002), The Composition of Bovine Milk Lipids: January 1995-December 2000. Journal Dairy Science; 85, 295-350.

Kaylegian, K. E., \& Lindsay, R.C. (1995). Handbook of Milk Fat Fractionation Technology and Applications. Journal of American Oil Chemists' Society Press, Champaign, Illinois, 662 pp

Kaylegian, Kerry, E., (1995), Functional Characteristics and Nontraditional Applications of Milk Lipid Components in Food and Nonfood Systems. Journal Dairy Research; 78, 2524-2540. 
Kholif, A.E. et al. (2018). Essential oils blend with a newly developed enzyme cocktail works synergistically to enhance feed utilization and milk production of Farafra ewes in the subtropics, Small Ruminant Research, 161, 43-50, https://doi.org/10.1016/j. smallrumres.2018.02.011.

Kholif, S. M. et al. (2012). Effect of Supplementing Lactating Goats Rations with Garlic, Cinnamon or Ginger Oils on Milk Yield, Milk Composition and Milk Fatty Acids Profile J Life Sci, 4(1): 27-34

Kotsampasi, B. et al. (2018). Effects of dietary orange peel essential oil supplementation on milkyield and composition, and blood and milk antioxidant status ofdairy ewes.Animal Feed Science and Technology, 245, pages:20-31

Martini, M. et al. (2004). Analisi morfometrica dei globuli di grasso del latte ovino e correlazioni con i parametri qualitativi. Ital. J. Anim. Sci.;3(1): 55-60.

Molle, G. et al. (2008). An update on the nutrition of dairy sheep grazing Mediterranean pastures. Small Rumin. Res.;77(2-3): 93-112.

Muñoz-Tébar, N. et al. (2019). Enrichment of sheep cheese with chia (Salvia hispanica L.) oil as a source of omega-3, LWT, 108, 407-415, https://doi.org/10.1016/j.lwt.2019.03.092.

Neto, O.B., Moreno, G. M. B., \& Souza AC, S. F. (2016). Effects of essential o1ls on dry matter intake and the milk production and composition in lactatıng ruminants: a review efeitos dos óleos Essencia1s sobre o. Ciência Veterinária nos Trópicos.;3(19): 49-57.

Nudda, A. et al. (2014). Feeding strategies to design the fatty acid profile of sheep milk and cheese. Rev. Bras. Zootec.;43(8): 445-56.

OECD-FAO., (2018). Chapter 7. Dairy and dairy products. OECD-FAO Agric. Outlook 20182027. 2018; 163-74.

Park, Y.W. et al. (2007). Physico-chemical characteristics of goat and sheep milk. Small Rumin. Res.;68(1-2): 88-113.

Pascual, A. et al. (2019). Effects of feeding UFA-rich cold-pressed oilseed cakes and sainfoin on dairy ewes' milk fatty acid profile and curd sensory properties, Small Ruminant Research, 175, 96-103, https://doi.org/10.1016/j.smallrumres.2019.04.009.

Pulina, G. et al. (2006). Effects of nutrition on the contents of fat, protein, somatic cells, aromatic compounds, and undesirable substances in sheep milk. Anim. Feed Sci.Technol.;131(3-4): 255-91.

Pulina, G. et al. (2018). Invited review: Current production trends, farm structures, and economics of the dairy sheep and goat sectors. J. Dairy Sci. ;101, 6715-6729.

Santos, DSD. et al. (2019). Benefits of the inclusion of açai oil in the diet of dairy sheep in heat stress on health and milk production and quality. $J$ Therm Biol. 84:250-258. doi: 10.1016/j.jtherbio.2019.07.007.

Santos, J. E. et al. (2013). The role of specific fatty acids on dairy cattle performance and fertility. Florida Ruminant Nutrition Symposium 6th february 2013.

Sharma, Neelesh, (2007), Alternative Approach to Control Intramammary Infection in Dairy Cows: A Review. Asian J. Anim. Vet. Adv.;2(2): 50-62. 
Simitzıs, P.E. et al. (2007). Effect of dietary oregano essential oil supplementattion on sheep milk characteristics.Animal Science Review.37 , 69-78

Silva, J. et al. (2003). Analgesic and anti-inflammatory effects of essential oils of Eucalyptus. $J$ Ethnopharmacol. Dec;89(2-3):277-83. doi: 10.1016/j.jep.2003.09.007. PMID: 14611892.

Symeou, S. et al. (2019). Nuclear magnetic resonance screening of changes in fatty acid and cholesterol content of ovine milk induced by ensiled olive cake inclusion in Chios sheep diets, Small Ruminant Research, 177, 111-116, https://doi.org/10.1016/j.smallrumres.2019.06.017.

Taissa, S. C. et al. (2017). Increasing dietary levels of citral oil on nutrient total tract digestibility, ruminal fermentation, and milk composition in Saanen goats. Animal Feed Science and Technology 229, 47-56

Torres, R.N.S. et al. (2020). Meta-analysis of the effects of essential oils on ruminal fermentation and performance of sheep, Small Ruminant Research, 189, 106148, https://doi.org/10.1016/j. smallrumres.2020.106148.

Tuik., (TURKSTAT) (2020). Turkey Statistical Institute

Vlaeminck, B. et al. (2006). Milk odd- and branched-chain fatty acids in relation to the rumen fermentation pattern. J. Dairy Sci. 89(10): 3954-64.

Wang, Y. et al. (2000). In vitro effects of steroidal saponins from Yucca schidigera extract on rumen microbial protein synthesis and ruminal fermentation. J. Sci. Food Agric.;80(14): 2114 22. 